inOedia $\quad \begin{aligned} & \text { InMedia } \\ & \text { The French Journal of Media Studies }\end{aligned}$

$3 \mid 2013$

Cinema and Marketing

\title{
Marketing Films to the American Conservative Christians: The Case of The Chronicles of Narnia
}

\author{
Nathalie Dupont
}

\section{(2) OpenEdition}

\section{Journals}

\section{Electronic version}

URL: http://journals.openedition.org/inmedia/594

DOI: $10.4000 /$ inmedia.594

ISSN: 2259-4728

\section{Publisher}

Center for Research on the English-Speaking World (CREW)

Electronic reference

Nathalie Dupont, « Marketing Films to the American Conservative Christians: The Case of The Chronicles of Narnia », InMedia [Online], 3 | 2013, Online since 22 April 2013, connection on 08 September 2020. URL : http://journals.openedition.org/inmedia/594 ; DOI : https://doi.org/10.4000/ inmedia.594

This text was automatically generated on 8 September 2020 .

(C) InMedia 


\title{
Marketing Films to the American Conservative Christians: The Case of The Chronicles of Narnia
}

\author{
Nathalie Dupont
}

The development of commercial cinema in the United States led to the search of proper stories able to attract audiences of all ages. Very rapidly silent films thus started using the Bible as a source of inspiration. But at the same time, other Hollywood films had storylines deemed immoral and too licentious by some American conservative Christians who wanted the young industry, mostly created in its modern form by Jewish immigrants, to amend itself. Whether Catholic or Protestant, those conservative Christians rapidly called for some control of Hollywood and were behind the "Hays Code' that regulated Hollywood's productions from the 1930s up to the 1960s.

Even if mores became somewhat more relaxed afterwards, conservative Christians ${ }^{1}$, together with other conservative Americans, have kept a watchful eye on Hollywood. Protestant and Catholic film agencies contributed to establish the 1968 Motion Picture Association of America (MPAA) classification, while conservative Christians did not hesitate to make themselves heard when they thought it necessary, such as with the controversy surrounding the production and then release of The Last Temptation of Christ (Martin Scorsese, 1988). They also approved the comments and analyses of conservative film critic Michael Medved who has kept lamenting over a now 'sick and far too liberal Hollywood' that undermines traditional American values. ${ }^{2}$

Therefore the studios' relationship with the American conservative Christians has always been a tricky one, as they are not an easy audience to satisfy. However, previous examples and the surprising box office success of The Passion of The Christ (Mel Gibson, 2004) underline that, in some cases, the American conservative Christians, and more particularly the Protestant ones, can become a financial asset as a niche audience for Hollywood. This article thus describes the reasons that pushed the producers and distributors of The Chronicles of Narnia to take advantage of that niche audience. It shows how they did it and came to collaborate with the American Evangelicals, ${ }^{3}$ who 
make an extensive use of modern methods of communication and welcome such highprofile opportunities to spread God's word. But it also demonstrates that in a globalized movie industry ruled by market shares and profits, Hollywood's overtures to the American conservative Christians cannot but be limited, as the latter remain a niche audience.

\section{The American Conservative Christians: An Interesting Audience for Hollywood and The Chronicles of Narnia?}

Hollywood has always been wary of conservative Christians and their renewed calls for censorship, but it does not mean that the studios have completely ignored them. For example, they worked with Catholic and Protestant representatives to create the Motion Picture Production code also known as the 'Hays code' that was implemented in 1934 and that regulated the content of American films until 1966. Producers also consulted religious leaders and involved them in the release of Bible epics such as The Ten Commandments (Cecil B. DeMille, 1956) or Ben Hur (William Wyler, 1959).

Then, during the last quarter of the $20^{\text {th }}$ century and the beginning of the $21^{\text {st }}$ century, conservative Protestant values became more visible in America, whether it be thanks to two Republican presidents, Ronald Reagan and the born-again George W. Bush, or to the ideas defended by the Tea Party. As Hollywood is an industry that relies on profits and market shares, it cannot ignore the increasing visibility and popularity of a certain trend and the financial potential that lies with its particular audience. Consequently, when Mel Gibson's The Passion of The Christ opened first at the American box office in 3,043 theatres at the end of February 2004, every major producer paid attention to what happened.

The film had first been thought the fancy and whims of a star, and destined to fail, all the more so as it was intended to be shot and released in Arameic, Latin and Hebrewwith English subtitles-, languages most Americans are not exactly familiar with. Yet, against all odds, the $\$ 30$ million R-rated production ${ }^{4}$ became a tremendous success, eventually making $\$ 370.78$ million at the American box office while staying in cinemas for 22 weeks. ${ }^{5}$ It turned out that conservative Protestants, and more particularly the Evangelicals, had played their part in that success. The Passion of The Christ thus revealed the potential of those American conservative Protestants as a niche audience that could be added to the more traditional and-sometimes-lay American audience.

Financially speaking, many observers also noted several interesting factors. At the beginning of the $21^{\text {st }}$ century, the business linked to the American Christian retailing industry was a booming one representing about $\$ 3$ billion in 2001-and $\$ 4.63$ billion in 2007. ${ }^{6}$ The tremendous success of the Left Behind Christian series of books that had become best sellers ${ }^{7}$ also showed that the Christian culture could cross over into the American mainstream culture. The conservative Christians were among the $25 \%$ to $40 \%$ Americans who go to church every week, ${ }^{8}$ usually as a family, while in cinemas, among the families with children, $41 \%$ were occasional moviegoers among those with children under the age of 12 , while they were $36 \%$ in case of families with teenagers. ${ }^{9}$ If studios offered conservative Christian families more films destined to please them, those families may become frequent moviegoers and thus may increase the box office potential of Hollywood films at a time when their traditional young audience of 12 to 24 
year-olds, which had stood at $42 \%$ of moviegoers in 1990, had decreased to $38 \%$ in 2004 .

Hollywood thus turned an interested eye to the conservative Christians, especially the Protestant ones, co-producing and/or releasing moderately budgeted films with a more obvious Christian subtext such as The Gospel (Rob Hardy, 2005) or The Nativity Story (Catherine Hardwicke, 2006). The scope of Walden's planned adaptation of The Chronicles of Narnia was more wide-reaching, as it belonged to the blockbuster category. But it was a project that could also please the conservative Protestant audience while representing a potential box office success for Hollywood, as no studio would just coproduce and distribute an expensive film solely destined to a niche audience.

The book series had been created by C.S. Lewis, an author who had extensively written and spoken about how he had converted back to his Anglican childhood faith in his thirties, and had since then been known as a Christian apologist among the Englishspeaking Christians. This Oxford and then Cambridge University Professor had often described how his Chronicles made of seven books had a very strong Christian context, with Aslan the lion standing for Jesus Christ while the journey undertaken by the main young British characters of the book was meant to elevate and better their souls as well as those of the people they met in Narnia.

Since the publication of the first volume in 1950, The Chronicles of Narnia had sold more than 100 million copies and become best-sellers in the English-speaking world as well as a required reading in numerous schools. Their Christian subtext had also made The Chronicles a popular reading among believers, especially among Evangelicals as the books could be used to explain and to spread essential Christian values. This had created a pool of potential spectators, a 'built-in' audience in Hollywood terms, who might be interested to see on the silver screen what they had imagined while reading the books. Adapting The Chronicles of Narnia thus represented the opportunity to create a cinematographic franchise that could follow in the footsteps of The Lord of the Rings, another successful adaptation-based on the books written by J. R. R. Tolkien, a fellowprofessor and friend of C.S. Lewis. ${ }^{11}$

The adaptations of The Chronicles of Narnia had the potential to become 'four-quadrant movies' like Titanic (James Cameron, 1997) or Spider-Man (Sam Raimi, 2002). In Hollywood terms, this means successful films that appeal to the important demographic quadrants of the audience: male, female, over and under 25 years old.

Finally, the studios were less reluctant to adapt books with an obvious British context. The tremendous success of the Harry Potter adaptations ${ }^{12}$ had proved the American and international audiences were ready to welcome films steeped in the British world The Chronicles of Narnia is imbued with. The Chronicles' main characters also enter Narnia in a way that resembles the way the wizards- and witches-to-be leave the muggles' world and enter their own at platform $93 / 4$ in Harry Potter and the Philosopher's/Sorcerer's Stone (Chris Columbus, 2001).

All those reasons led Walt Disney Pictures to accept readily the partnership with Walden Media when the latter approached them to co-produce and distribute The Chronicles of Narnia: the Lion, the Witch and the Wardrobe (Andrew Adamson, 2005). 


\section{Marketing The Chronicles of Narnia to the American Conservative Christians}

The project was the brainchild of Walden Media and its financial backer, conservative evangelical billionaire Philip Anschutz. With his help, the company had acquired from C. S. Lewis Pte. Ltd. the adaptation rights for three Chronicles books. These books suited Philip Anschutz's desire as far as film production was concerned, a desire he made clear in one of his extremely rare speeches in 2004: "[...] four or five years ago, I decided to stop cursing the darkness-I had been complaining about movies and their content for years-and instead to do something about it by getting into the film business [...]." ${ }^{13}$ Those words point to a moral and spiritual agenda, which explains why Philip Anschutz was interested when Michael Flaherty and Cary Granat, who were looking for finances, talked to him about their family-oriented media project that would educate and entertain people without using foul language, sex, violence or drugs. Philip Anschutz decided to invest in what became Walden Media, which was created in 2001. The company intended to "tell stories that recapture imagination, rekindle curiosity, and demonstrate the rewards of virtue" ${ }^{14}$ through the adaptation of children's books that should be suitable for family viewing. The Chronicles of Narnia thus perfectly suited Walden's production agenda.

Knowing the film would cost a lot of money to produce, distribute and market, Walden Media looked for an associate,,$^{15}$ and Walt Disney Pictures stepped in to share the production costs and American profits on a 50/50 basis, while it was also to distribute the film in the United States and abroad through its Buena Vista international division.

The film eventually cost about $\$ 180$ million to produce and about $\$ 120$ million to market, bringing the total cost to roughly $\$ 300$ million. As the price tag was very high, the film's producers considered every audience that could bring in more money, and the conservative Protestant audience, more particularly the evangelical one, became an obvious choice in the wake of the success of The Passion of the Christ and the marketing practices that had targeted that particular audience. Disney and Walden thus agreed to sub-contract the Christian niche marketing to Motive Marketing, the very company that had already handled the advertisement for Mel Gibson's film.

Together with the more traditional marketing handled by Walt Disney Pictures, ${ }^{16}$ the niche marketing targeting the American conservative Christians began months before the release of the film that was scheduled for December 2005. There was a teaser/ trailer released in the summer of 2005 at several Christian festivals. Then, at the beginning of September 2005, some of the artists who had recorded an album of songs inspired by the film performed live at 'Night of Joy,' the annual Christian music festival held at Disney's Magic Kingdom theme park in Florida.

From September 2005 onwards, Motive also used churches to spread the word about the coming of Narnia, particularly relying on megachurches. ${ }^{17}$ This was for example the case in New York at the non-denominational Christian Cultural Center in Brooklyn. There, the megachurch congregation watched exclusive clips, were given gift bags full of outreach material, and listened to a special live performance by Christian music star Steven Curtis Chapman who had recorded a song on the album inspired by the film and produced by Sparrow Records, the Christian label owned by EMI. ${ }^{18}$ People were also able to discuss the making of the movie with Douglas Gresham, C.S. Lewis' stepson and 
a co-producer of the film, and with Michael Flaherty, Walden Media President-both men are committed Protestants. ${ }^{19}$

Throughout the United States, a few handpicked influential pastors and evangelical leaders were also invited to 'Narnia Outreach Training Seminars' that included the showing of a Powerpoint presentation, together with the trailer and some movie clips that could then be found on the Internet. They were also introduced to the Christian resources especially created for the film and that could be downloaded on the site set up by Motive Marketing. ${ }^{20}$ The company also enlisted the help of the Christian society Outreach Media Inc. that, through its site, invited more pastors and evangelical leaders to about 100 'Narnia Sneek Peeks' organized throughout the country, and more particularly in the South of the United States, in the so-called conservative Bible Belt where part of the film's niche audience could be located. The Internet site sermoncentral.com, property of Outreach, also provided religious leaders with free online Narnia-inspired sermons. For example, the sermon entitled "Narnia: The King is on the Move!" equated the coming of Aslan to free Narnia from its everlasting winter and its evil Queen Jadis with that of Christ to save mankind from its sins. ${ }^{21}$ The site also launched a promotional sermon contest with a trip to London and $\$ 1,000$ for the winning pastor.

Motive Marketing also contacted powerful and influential evangelical organizations. The latter welcome such initiatives as they represent another opportunity to "go into all the world and preach the gospel,"22 one of the basic tenets of Evangelicalism. To do so, Evangelicals rely on modern means of communication like radio, television, cinema $^{23}$ and now Internet. As The Chronicles of Narnia: the Lion, the Witch and the Wardrobe was the example of films that fit their tastes and values, and that can be used for Christian outreach, evangelical organizations such as Campus Crusade for Christ or the National Association of Evangelicals agreed to broadcast the film trailer on their television channels. Motive also got a positive response from the evangelical group Focus on the Family that, in spite of its previous condemnation of Disney for its gayfriendly policy, nevertheless announced it officially endorsed the new film via an email to the popular culture magazine Entertainment Weekly.

All those actions were part of a marketing method called replicasting, thus defined by Paul Lauer, the founder of Motive Marketing:

We target pastors, teachers, youth leaders, speakers, authors, influencers, heads of organizations or even a really on-fire mom [...] We create that bond with these channel partners, and we then equip them to narrow-cast to their group. They then become receivers and transmitters. ${ }^{24}$

So, through various Christian channels, Motive Marketing was able to build a 'Narnia awareness' designed to reach its climax and full potential among the American Protestant community in December 2005, as the film was about to be released. Then, the commitment of evangelical congregations to the marketing of The Lion, the Witch and the Wardrobe even led them to make advance bookings for the pre-opening screenings that took place the day before the official release. ${ }^{25}$ Consequently, the 36,000 -odd registered pre-bookings placed the film at the top of advance bookings, ahead of those for Harry Potter and the Goblet of Fire (Mike Newell, 2005) and King Kong (Peter Jackson, 2005), which was quite a feat. ${ }^{26}$ This, in turn, attracted the attention of cinema owners and convinced those who might have hesitated that the film 'could have legs at the box office'-as Hollywood puts it-and was a potential blockbuster. 
When The Lion, the Witch and the Wardrobe opened on December 9, 2005 in 3,616 cinemas, the combination of classic and niche marketing campaigns allowed it to rank first with a box office of $\$ 65.56$ million and an excellent average of $\$ 18,129$ per site. The influential Christian Internet site Movieguide, ${ }^{27}$ which rates films from a Christian perspective for family-friendly entertainment, noted a few differences between the book and the film. But the review underlined that The Lion, the Witch and the Wardrobe" retain[ed] most of its Christian focus" and was a "spectacular movie, tremendously exciting, thrilling and redemptive." ${ }^{28}$ The film then stayed in cinemas for 22 weeks, and eventually grossed $\$ 291.71$ million in the United States and $\$ 453.30$ million abroad.

All was boding well for the second instalment entitled The Chronicles of Narnia: Prince Caspian (Andrew Adamson, 2008). But Hollywood's rules took precedent and this led to a big disappointment. The Chronicles of Narnia: Prince Caspian was again a Walt Disney Pictures-Walden Media co-production. Thinking that the family and the conservative Protestant audiences were now acquired, Disney, still in charge of marketing and distributing the film, opted for a new strategy for Prince Caspian. The studio decided against financing any specific niche marketing targeting the conservative Christian audience. Christian Internet sites and newspapers did publish articles on the film, together with some interviews from cast members and producers, Outreach still offered ministers the possibility to download specific sermons from Sermon Central, but all this was part of the normal Christian attention paid to a film that had Christian undertones. The only official resources linked to the producers of the film were those for educators that could be found on the Walden Internet site and that accompany every single film produced by Walden Media. Its representatives, especially Michael Flaherty, together with Douglas Gresham, also discussed with leading members of the Protestant community and gave interviews to Christian newspapers and magazines. But Walden Media and Walt Disney Pictures did not plan or sub-contract the organization of any real preview destined to the conservative Protestant niche, nor did Disney allot any percentage of the $\$ 175$-odd million marketing budget to specific Christian resources.

In fact, the Disney team distributing Prince Caspian seemed to handle the film as a 'normal' potential summer blockbuster principally targeting the young audience, and booked the $\$ 225$ million production for a summer release on May 16, 2008. But in doing so, the studio made several mistakes.

Disney literally sandwiched the film between what Hollywood sometimes calls 'summer behemoths': Iron Man (Jon Favreau, May 2, 2008) and Indiana Jones and the Kingdom of the Crystal Skull (Steven Spielberg, May 22, 2008). It was not an easy slot to occupy if Prince Caspian wanted to keep its audience after its first week of release. On May 19, The Hollywood Reporter wrote that the film had made $\$ 56.6$ million, which put it ahead of Iron Man and at the top of the box office ranking. But the article emphasized that the film was in fact underperforming as many observers had expected $\$ 80$ million on Prince Caspian's opening week. Chuck Viane, Disney's distribution president, commented on Prince Caspian's box office while trying to justify its release date:

We're off to a good start-not great, but good [...] I don't think it's written anywhere that movies open and outperform the originals. It's not a truism. [...] The safest thing in the world is always to put the (sequel) back where (the original) opened [...]. But I believe this picture plays so broadly that you want the biggest audience you can have. ${ }^{29}$ 
The Disney team said they wanted a broad audience, but as Prince Caspian was more sombre than The Lion, the Witch and the Wardrobe and featured many battles, Disney opted to essentially court the young male audience that had transformed The Lord of the Rings into a successful franchise. The trailers for Prince Caspian thus insisted that "you may find Narnia a more savage place than you remember," while they displayed numerous scenes of battles and sword fights that were not really counterbalanced by more friendly scenes featuring Aslan. This was an important difference with the trailer for The Chronicles of Narnia: the Lion, the Witch and the Wardrobe, as revealed by the French software Lignes de Temps. ${ }^{30}$ Whereas the percentage of scenes showing Aslan or having a Christian subtext amounted to $41 \%$ of The The Lion, the Witch and the Wardrobe's official trailer, Prince Caspian's only featured $12 \%$.

Disney's gamble did not pay off as it put off the family and the conservative Christian audiences, while young patrons were moderately interested in the film and rapidly switched to Indiana Jones and the Kingdom of the Crystal Skull. After one month, Prince Caspian's figures lagged behind those of The Lion, the Witch and the Wardrobe, heralding a disappointing American box office of just $\$ 141.62$ million. This led some conservative Protestants and fans of the films to say that Disney had damaged the film's potential by deliberately ignoring them during the marketing of Prince Caspian. Its foreign box office of $\$ 278.04$ million also turned out to be disappointing, which Walt Disney Pictures considered as a bad omen. Having box office success abroad is indeed part and parcel of the studios' way of doing business, all the more so as in a now global economy, expensive American blockbusters often depend on their foreign box office to make up for possible failures at home. ${ }^{31}$ The foreign box office of Prince Caspian did not match Walt Disney Pictures' expectations, and fearing another costly international disappointment with the third adaptation-already in pre-production-, the studio decided to quit the franchise at the end of 2008.

At the beginning of 2009, different trade publications announced that Fox 2000 Pictures, a division of $20^{\text {th }}$ Century Fox Film Corp., was on board with Walden Media to co-produce and distribute the third instalment entitled The Voyage of the Dawn Treader (Michael Apted, 2010). Its release and marketing went through a complete about-face after the box office failure of Prince Caspian.

Initially slotted for a May 2010 release, when Disney was still a co-producing partner, the now Fox-Walden co-production re-integrated the December slot that had worked well for The Lion, the Witch and the Wardrobe, and was to be released in December 2010.

But for the marketing of The Voyage of the Dawn Treader, the Fox team was facing a difficult task, and Chris Aronson, Fox's distribution vice-president even talked of the necessity of resuscitating the franchise. This included collaborating with the Christian community once again-more particularly with the Evangelicals-and organizing a niche marketing via Motive Marketing and Grace Hill Media-alongside the more classic marketing campaign.

In February 2010, Fox 2000 Pictures and Walden Media organized in Los Angeles a twoday conference called 'Narnia Summit' that gathered about 100 religious leaders as well as fans' websites and evangelical organizations like Focus on the Family, Youth for Christ or Young Life. The participants listened to Michael Flaherty, the president of Walden Media, Douglas Gresham, Mark Johnson, the film's director, or Elizabeth Gabler, president of Fox 2000 Pictures. They were also shown the storyboard and a few clips from the film. 
In June 2010, Christian Internet sites such as Movieguide.com, Christianity Today.com or Focus on the Family.com were also allowed to show the first official trailer ahead of more lay sites such as Apple trailers, Yahoo or MSN. The use of Lignes de temps reveals that in this official trailer, the percentage of scenes showing Aslan or having a Christian subtext was up to $24 \%$-from $12 \%$ in Prince Caspian's-while the number of battle scenes was reduced to a mere $1 \%$.

From July to December 2010, the evangelical relief organization Samaritan's Purse set up 'Operation Narnia'. ${ }^{22}$ Via a video clip featuring Georgie Henley/Lucy, young Evangelicals were invited to decorate and then fill shoeboxes with useful presents for children. The boxes would be Christmas gifts to needy children around the world. The community that collected the most boxes was to welcome the official premiere of the film with Georgie Henley and Will Poulter/Eustace in attendance. ${ }^{33}$

The fact that the conservative Christian community was also targeted became more obvious in November with a second trailer that revealed the ending ${ }^{34}$ right from its start and contained lines of dialogue such as: " 'It seeks to corrupt all goodness' [...] 'It steals the light from this world' [...] 'Aslan's country' [...] 'do you really believe there's such a place?' 'we have nothing if not belief!'." 35

A few weeks before the release of the film, more ministers, pastors and evangelical leaders were invited to previews so as to then 'spread the good word' on Voyage of the Dawn Treader to their congregations. To do so they could also use the numerous resources found on Narnia Faith.com, the Internet site set up by Fox and Walden.

Repeating what had been done for The Lion, the Witch and the Wardrobe, the site also invited the spiritual leaders to "join Aslan, join the adventure in taking [their] congregation to the Voyage of the Dawn Treader" via group sales. ${ }^{36}$ The producers hoped that advance group bookings would enable the film to have a good first weekend at the box office.

Released on December 10, 2010 in 3,555 cinemas, The Voyage of the Dawn Treader ranked first with a box office of $\$ 24$ million $^{37}$ and an average of $\$ 6,752$ per site. Exit surveys showed that the film "attracted audiences comprising $51 \%$ of females, with $52 \%$ of patrons aged 25 or older and $44 \%$ of support coming from family moviegoers, ${ }^{\prime 38}$ which is what Fox and Walden had hoped for.

However, the box office was disappointing as it was already behind those of the previous installments' opening weekends. The Voyage of the Dawn Treader stayed in cinemas for 18 weeks and eventually grossed $\$ 104.39$ million in the United States and $\$ 311.30$ million abroad. The niche marketing had contributed to push more conservative Protestant families to watch The Voyage of the Dawn Treader, but it was far from enough to rescue the costly franchise in the United States, while its international box office barely satisfied its producers.

\section{The Limits of the Christian Niche Marketing in a Hollywood Context}

The Chronicles of Narnia came to represent the meeting point between different points of view on films. For the studios, the aim was to increase the box office of expensive films by adding a potential niche audience to their regular one. Walden Media shared that goal, while it also wanted to educate the audience and spark their imagination with 
entertaining all-ages productions having a moral, uplifting and Christian subtext-that could only be advertised within the confines of American churches and evangelical congregations. For the conservative Christian community, and more particularly for the Evangelicals, the films represented an opportunity to spread the word of Christ as was made clear by the evangelical Mission Coalition America:

The Chronicles of Narnia fantasy adventure series is just the right thing to penetrate today's culture in ways that more overt Christian films may not be able to do. We believe the release of this film is truly a unique opportunity that God has created. By clearly conveying the message of Christ and the Cross, it can serve as a powerful evangelistic tool. ${ }^{39}$

Within the Protestant community, some did not share the Evangelicals' enthusiasm and involvement in the marketing of The Chronicles of Narnia. Some pastors denounced the intrusion of Hollywood merchants into the temple. They felt used and almost soiled, as shown by the following reactions: "How crassly is the church being used?" asked one pastor in the Christian Post, ${ }^{40}$ while another half-jokingly denounced the intrusion of marketing into church services:

The obvious question is how far will it go? Where do we, as church leaders entrusted with the ministry of the Gospel, draw the line? When do we become guilty of serving both God and money (or the corporations seeking to make it)? Maybe your next baptism service could be sponsored by Evian? Perhaps Nintendo can take out advertising space in your children's ministry newsletter, or maybe you're content with just having a Mouse on your shoulder while you preach. ${ }^{41}$

Nevertheless, a sort of partnership, albeit limited, was created that managed to find a good balance between different goals, leading two types of marketing to co-exist for The Lion, the Witch and the Wardrobe and The Voyage of the Dawn Treader.

But this could only work if the more general audience was interested in the films, and throughout the process, the co-producing studios were cautious. They hoped the adaptations would be 'four-quadrant' films, but they certainly did not want the Christian niche marketing to drive away their usual young audience that does not really want to be preached at. The fact that Walden, together with Disney and then Fox, sub-contracted the Christian niche marketing is another proof that the studios were very cautious with it. Walt Disney Pictures was reportedly annoyed by the level of media attention lavished on the Christian niche marketing for The Lion, the Witch and the Wardrobe. Consequently, it refused to comment on its efficiency, as well as it refused to publish the result of the exit surveys carried out on that topic. As for Walden officials, they mainly stressed the educational value of the film. For example, they put forward how the opening scenes showing children being evacuated from Blitz-stricken London could find an echo with the then-recent catastrophe brought about by hurricane Katrina in Florida in August 2005. But Walden officials did not really insist on the Christian aspect and neither did Michael Flaherty: "In terms of how the film can be used at church, we're out of depth there [...] We offer no advice on how to do that." ${ }^{42}$

This desire to keep the Christian niche marketing as discreet as possible and the uneasiness from Disney and Walden on that topic also appeared in the way the actors were briefed for the promotion of the film. Tilda Swinton, who played the white witch in The Lion, the Witch and the Wardrobe, described it thus:

Last year [...] in the process of promoting two fantasy films [The Lion, the Witch and the Wardrobe and Constantine] for different Hollywood studios, I was advised on the proper 
protocol for talking about religion in America today. In brief, the directive was, hold your hands high where all can see them, step away from the vehicle and enunciate clearly, nothing to declare. ${ }^{43}$

For the co-producing and distributing Walt Disney Pictures, the Christian niche marketing around The Lion, the Witch and the Wardrobe was a small-size event to which only $5 \%$ of the film's marketing budget had been allotted, and its visibility and impact were only destined to stay within the confines of American churches and evangelical congregations.

In fact, Disney's reaction, as well as Walden's to a lesser extent, is perfectly understandable, and befits Hollywood's way of doing business. At a time of declining audience ${ }^{44}$ and ever-increasing production costs, Disney's aim, and then Fox's, was to take advantage of the possibilities offered by the conservative Protestant niche market and simply to add that audience to the other regular young one that has been at the root of Hollywood's successful films since the release of Star Wars (George Lucas) in 1977. To advertise openly The Lion, The Witch and the Wardrobe and then The Voyage of the Dawn Treader as Christian films would have raised a lot of eyebrows among the 'general' American and world audiences, while it would have antagonized the classic young and sometimes lay audience that most of the time just wants to be entertained.

When Disney booked Prince Caspian as a possible summer box office, it also followed Hollywood's rules and style of doing business. American blockbusters are traditionally released during the summer, and taking into consideration The Lion, the Witch and the Wardrobe's box office, Disney had every reason to believe that Prince Caspian would follow in its footstep and be a similar blockbuster, so better treat the film like all other potential blockbusters. But the film industry is an uncertain business where there is no true recipe for success, as was shown in 2007 by a study entitled Do Movies Make Money? ${ }^{45}$ When this happens in a now globalized world, where sometimes the foreign box office of a film cannot really make up for its disappointing American counterpart, it can lead a studio to reconsider its involvement in a franchise, as happened when Walt Disney Pictures withdrew from the adaptation of The Chronicles of Narnia: the Voyage of the Dawn Treader.

As Walden Media could not operate in Hollywood without a reliable co-production and distribution partner, it was forced to seek out a new co-producing partner it eventually found in Fox. However, in spite of its renewed courtship of the conservative Christian niche audience, the now Fox-Walden The Voyage of the Dawn Treader rapidly stood behind the figures of Prince Caspian, and also proved to be a disappointment at the box office in the United States and abroad as the general audience seemed less interested in it. This seems to have put a-temporary?-end to the adaptations of C.S. Lewis series, all the more so as the adaptation rights have now to be re-negotiated. ${ }^{46}$

As William D. Romanoswki said, "As a crucial medium of communication, movies are enmeshed in, and bear the marks of, religious, cultural, and class conflicts throughout the twentieth century." ${ }^{47}$ The recent filmed adaptations of The Chronicles of Narnia are an example of this and are anchored in a very precise American context. On the one hand, the films and the company that are at their origin are derived from the will of two founders and a conservative Christian billionaire who have a very precise agenda. On the other hand, there is the American film business that has an established audience but also wishes to broaden it in reaching out to a niche one. The American conservative Christians, and more particularly the Evangelicals, can contribute to the success of a 
film, and The Passion of the Christ as well as The Chronicles of Narnia have shown it, but their impact is nevertheless limited, especially in a now global economy. Abroad, Disney and Fox handled The Chronicles of Narnia like any other Hollywood films for children and family viewing. Even if the evangelical community is growing throughout the world, the Christian subtext was once again confined to a limited marketing targeting some British Christian communities and, in the case of Voyage of the Dawn Treader, to resources in six languages developed in collaboration with the World Evangelical Alliance.

There is no denying that Walden Media has a precise educational, moral and subdued religious agenda, as noticed by academic articles. ${ }^{48}$ Consequently, the company stands apart from other production companies, and its co-productions ${ }^{49}$ certainly have a 'Walden touch'. But they are destined for a general audience, not a niche one, and consequently have to follow Hollywood's way of doing business. For the studios and the independent companies that work with them, marketing films to conservative Christians is thus a limited business and a purely American phenomenon that cannot really be exported.

\section{BIBLIOGRAPHY}

Angulo Chen, Sandie. "Perspective from a Christian Critic," Variety, April 2, 2007. <http:// www.variety.com> (accessed December 30, 2010).

Augros, Joël \& Kitsopanidou, Kira. L'économie du cinéma américain. Paris: Armand Collin, 2009.

Ben Barka, Mokhtar. La Droite chrétienne américaine. Toulouse : éditions Privat, 2006.

Bond, Paul. “A Royal Release Date Mistake.” The Hollywood Reporter, May 29, 2008. <http:// www.hollywoodreporter.com/news/a-royal-release-date-mistake-112761 > (accessed January 3, 2011).

“'Dawn Treader' Studios reach out to influential Christians with 'NarniaFaith' Website, Screenings." The Hollywood Reporter, December 7, 2010. <http://www.hollywoodreporter.com/ news/dawn-treader-studios-reach-influential-57307> (accessed January 3, 2012).

Boorstein, Micelle. "Religious retailers do a bit of soul-searching this Christmas," The Washington Post, December 21, 2010. <http://www.washingtonpost.com> (accessed December 28, 2010).

Bordwell, David, Staiger, Janet \& Thompson, Kristin. The Classical Hollywood Cinema. London: Routledge, 1985.

Cohen S. David. "Hollywood gets Religion.” Variety, 403 2, (May 29- June 4, 2006): 6.

“Execs say Prayers for next 'Passion'.” Variety, April 2, 2007. <http://www.variety.com/article/ VR1117962419?refCatId=2530> (accessed December 30, 2010).

Di Orio, Carl. “'Prince' not so charming." The Hollywood Reporter, May 19, 2008. <http:// www.hollywoodreporter.com/news/prince-not-so-charming-1114555> (accessed January 3 , 2012). 
Doherty, Thomas. Hollywood's Censor. New York: Columbia University Press, 2007.

Dunkley, Cathy. "Mouse making Narnia Myths." Variety, March 1st, 2004. <http:// ww.variety.com/article/VR1117901006? categoryid=13\&cs=1> (accessed April 24, 2012).

Dupont, Nathalie. "Hollywood and the American Christian groups: a business partnership." Religion, Secularity and Cultural Agency, 74 (accessed January 2010): 173-193.

Faith, Sébastien. Dieu XXL. Paris: Autrement, 2008.

Flynn, Gillian and Jansen, Jeff. "Christian Entertainment Part 2: the next Temptation," Entertainment Weekly, December 10, 1999. <http://www.ew.com> (accessed December 12, 2011). Giles, Jeff. “This just in: Movies don't make Money”. Variety, November 13, 2007. < http:// www.variety.com/article/VR1117975782/?categoryid=13\&cs=1> (accessed January 27, 2008). Gomery, Douglas. The Hollywood Studio System. London: British Film Institute, 2005.

Kay, Jeremy. "The Lion, The Witch and Walden Media." Screen International, 1526 (December 2, 2005): 8.

King, Geoff, Molloy, Claire, and Tzioumakis, Yannis, eds. American Independent Cinema. New York: Routledge, 2013.

Lacorne, Denis. De la religion en Amérique. Paris : Editions Gallimard, 2007.

Lindvall, Terry. Sanctuary Cinema. New York: New York University Press, 2007.

Lowry, Brian. “Can H'wood make Friends with Evangelicals?” Variety, October 21, 2011. <http:// www. www.variety.com/article/VR1117956507> (accessed June 5, 2012).

Medved, Michael. Hollywood vs. America. London: HarperCollins, 1992.

Mitchell, Wendy. "Churches out to boost the Lion's Share of the Box office." Screen International, November 16, 2005. <http://www.screendaily.com> (accessed November 19, 2005).

Phan, Katherine T. “'Voyage of the Dawn Treader' Website reaches out to Pastors." The Christian Post, November 13, 2010. <http://www.christianpost.com/news/voyage-of-the-dawn-treaderwebsite-reaches-out- to-pastors-47619> (accessed November 26, 2010).

Portes, Jacques. De la scène à l'écran. Paris : Belin, 1997.

Ramachandran, Naman. "The many Languages of 'Narnia'." Variety, December 4, 2010. <http:// www.variety.com/article/VR1118028377> (accessed December 28, 2010).

Romanoswki, William D. Reforming Hollywood: how American Protestants Fought for Freedom at the Movies. New York: Oxford University Press, 2012.

Russell, James. "Narnia as a Site of National Struggle: Marketing, Christianity, and National Purpose in The Chronicles of Narnia: The Lion, the Witch and the Wardrobe." Cinema Journal, 484 (summer 2009): 59-76.

Sheldon, Hall. "Selling Religion: how to market a Biblical Epic." Film history, 142 (2002):170-185.

Schultze, Quentin J. \& Woods, Robert H., eds. Understanding Evangelical Media. Downers Grove: InterVarsity Press, 2008.

Tse, Rhoda. "Churches cautioned against rallying to all Christian-targeted Movies", The Christian Post, November 11, 2005. <http://www.christianpost.com> (accessed December 13, 2012). 


\section{Webography}

< http://www.theamericanchurch.org>.

<http://www.boxofficemojo.com>.

$<$ http://www.christianpost.com>.

$<$ http://www.christianitytoday.com>.

$<$ http://www.ew.com>.

<http://www.hollywoodreporter.com>.

$<$ http://www.imdb.com>.

< http://www.missionamerica.org>.

$<$ http://www.movieguide.com>.

$<$ http://www.mpaa.com>.

$<$ http://www.narniasources.com>.

$<$ http://www.narniaweb.com>.

< http://www.operationnarnia.org>.

$<$ http://religions.pewforum.org>.

$<$ http://www.sermoncentral.com>.

$<$ http://www.variety.com>.

$<$ http://www.waldenmedia.com>.

$<$ http://www.washingtonpost.com>.

\section{NOTES}

1. In this article the words American conservative Christians essentially mean American conservative Protestants, as they are the main target of a specific niche marketing. Trade sources do not mention any specific marketing targeting the American Catholics. Some data come from personal archives, notably MPA reports that can no longer be accessed on Internet. This is also the case with some study guides linked to the films.

2. The Jewish syndicated radio talk show host, author and film critic notably published the bestseller Hollywood vs. America: Popular Culture and the War on Traditional Values in 1992, and co-hosted Sneak-Previews on PBS between 1984 and 1996.

3. Evangelicalism is a branch of Protestantism. "Evangelicals believe that one must be 'born again', through personal crisis; that one must follow the dictates of the Bible with relative strictness; that the 'second coming' of Christ will occur; that one has a divinely inspired duty to spread the word of Christ salvation, and, crucially, that all aspects of public and private life present an opportunity to honour God." James Russell, "Independent Christian marketing," in American Independent Cinema, eds. Geoff King, Claire Molloy and Yannis Tzioumakis (New York: Routledge, 2013), 187.

4. In America, the MPAA rating system is as follows: $G$ for general audiences (all ages admitted), PG for parental guidance suggested (some material may not be suitable for children), PG-13 for parents strongly cautioned (some material may be inappropriate for children under 13), $\mathrm{R}$ for 
restricted (under 17 requires accompanying parent or adult guardian), and NC-17 for no one 17 and under admitted.

5. It also made $\$ 241.116$ million abroad. Box Office Mojo, http://www.boxofficemojo.com/ movies/?id=passionofthechrist.htm <accessed June 22, 2012>.

6. Jeff Jansen and Gillian Flynn, "Christian Entertainment Part 2: the next Temptation," Entertainment Weekly, December 10, 1999. http://www.ew.com <accessed December 12, 2011>, Marc Peyser, “God, Mammon, \& 'Bibleman'," Newsweek, July 15, 2001. http:// www.thedailybeast.com/newsweek.html <accessed December 10, 2011>, Annalee Ward, "Faithbased Theme Parks and Musems," in Understanding Evangelical Media, eds Quentin J. Schultze and Robert H. Woods Jr. (Downers Grove: InterVarsity Press, 2008), 175 and Michelle Boorstein, "Religious retailers do a bit of soul-searching this Christmas," The Washington Post, December 21, 2010. http://www.washingtonpost.com <accessed December 28, 2010>.

7. And, in the case of their filmed adaptations, blockbusters in American megachurches.

8. That is to say between 90 to 120 million people from different denominations. Figures vary depending on sources, and observers note that while answering surveys, some Americans say they go to church every week even if they actually don't. Religious Tolerance, http:// www.religioustolerance.org/rel_rate.htm <accessed November 19, 2011>, The American Church, http://www.theamericanchurch.org/facts/6.htm <accessed November 20, 2011> and Religious Beliefs and Practices in the United States, http://religions.pewforum.org/maps <accessed January 21, 2013>.

9. 1992 Motion Picture Almanac, New York: Quigley Publishing Company, 24 and 2005 U.S. Movie Attendance Studies, http://www.mpaa.org <accessed June 22, 2005>. According to the Motion Picture association of America, an occasional moviegoer is someone who watches a film in a cinema at least once in 6 months.

10. A frequent moviegoer is someone who watches a film in a cinema at least once per month. Motion Picture Association of America, 2000 \& 2004 U.S. Movie Attendance Studies, http:// www.mpaa.org <accessed on June 16, 2001 and June 22, 2005>.

11. These books also have Christian undertones.

12. In 2004, the adaptations of the first three Harry Potter books had already earned $\$ 829.104$ million at the American box office. Box Office Mojo, http://www.boxofficemojo.com/search/? q=Harry\%20Potter <accessed June 23, 2012>.

13. Mark Moring, "Hollywood Hellfighter," Christianity Today, May 13, 2008. http:// www.christianitytoday.com/ct/article_print.html?id=55249 <accessed November 12, 2010>.

14. Walden Media, http://www.walden.com <accessed June 9, 2012>.

15. Walden Media is a production company that does not have any distribution arm. When The Lion, the Witch and the Wardrobe was released in 2005, the average production cost of a studio film was $\$ 63.6$ million according to MPAA figures while the marketing cost was $\$ 36.1$ million. Motion Picture Association of America, “2006 U.S. Theatrical Market Statistics," http://www.mpaa.org $<$ accessed April 18, 2007>.

16. Which included, among other things, toys, a tie-in agreement with MacDonald's or an attraction called Journey into Narnia: the Lion, the Witch and the Wardrobe at Disney's Hollywood Studios in Florida.

17. The megachurches can accommodate such events as they have top-of-the-range screens and audio equipment that can rival those found in cinemas.

18. The album, called Music inspired by The Lion, the Witch and the Wardrobe, was released on September 27, 2005, well ahead of the official soundtrack album, produced by Walt Disney Studios, that was released on December 13, 2005.

19. Michael Flaherty became an Evangelical in 1999. http://sixseeds.tv/s/content/movies/696interview_with_walden_media_president_mike_flaherty <accessed March 25, 2011>.

20. http://www.narniasources.com <accessed March 16, 2006>. 
21. http://www.sermoncentral.com <accessed November 25, 2010>.

22. The Bible, Mark 16:15. New International Version.

23. The first regular evangelical radio broadcast began in 1921. In 1951, the evangelist Billy Graham created WorldWide Pictures, a film production and distribution company. He also started broadcasting evangelical TV programmes in the 1950s. From the end of the 1970s onwards, televangelists became even more numerous with the development of satellite and cable television networks. Paul A. Creasman, "Looking beyond Radio for Listeners," Kathy Bruner, "Thinking outside the tribal TV Box," and Terry Lindvall and Andrew Quicke, "Moving from Film to Digital Movies," in Understanding Evangelical Media, 36, 53 and 59.

24. David S. Cohen, "Execs say Prayers for next 'Passion'," Variety, April 2, 2007. http:// www.variety.com <accessed October 29, 2012>.

25. In a repetition of what had already contributed to the box office success of The Passion of the Christ.

26. Chris Gardner, "Walden looks for Lion's Share," Variety, December 11, 2005. http:// www.variety.com <accessed November 13, 2011>.

27. In 2007, it was accessed by an average of 3 million people per month, and its newsletter was sent to about 11 million Internet addresses. Sandie Angulo Chen, "Perspective from a Christian Critic," Variety, April 2, 2007. http://www.variety.com <accessed December 30, 2010>.

28. Movieguide, "The Chronicles of Narnia: the Lion, the Witch and the Wardrobe," December 9 , 2005. http://www.movieguide.org/reviews/1-2471.html/ <accessed January 10, 2013>.

29. Carl DiOrio, “Prince' not so charming," The Hollywood Reporter, May 19, 2008. http:// www.hollywoodreporter.com/news/prince-not-charming-112043 <accessed June 26, 2012>.

30. Lignes de temps was developed by IRI-Institut de Recherches et d'Innovation. http:// www.iri.centrepompidou.fr/outils/lignes-de-temps/?lang=fr_fr <accessed January 28, 2012>.

31. As was for example the case with Troy (Wolfgang Petersen, 2004) that cost $\$ 175$ million to produce, earned $\$ 133.38$ million at the American box office and $\$ 364.03$ million abroad.

32. Operation Narnia, http://www.operationnarnia.org, <accessed June 9, 2012>.

33. The winner was the Christian Academy of Louisville in Kentucky.

34. Many conservative Christians were particularly anxious about it as it is when Lucy understands she will not come back to Narnia and is told by Aslan that in her world she must learn to know him by another name (Jesus Christ in the subtext).

35. Narnia Faith, http://www.narniafaith.com/learn/the-voyage-of-the-dawn-treader-trailer $<$ accessed June, 15, 2012>.

36. Narnia Faith, http://www.narniafaith.com/engage/group-sales <accessed May 26, 2012>.

37. $54 \%$ of that box office came from the 1,988 cinemas that were showing the film in 3-D.

38. Carl DiOrio, “Underwhelming 'Narnia's' $\$ 24.5$ Mil Debut Weekend Still Manages to Top 'Tourist'," The Hollywood Reporter, December 12, 2010. http://www.hollywoodreporter.com/news/ narnias-245-mil-debut-weekend-59052 <accessed July 2, 2012).

39. Mission coalition America, "The Chronicles of Narnia and Outreach Opportunities!," http:// www.missionamerica.org <accessed September 12, 2005>.

40. Rhoda Tse, "Churches cautioned against rallying to all Christian-targeted Movies", The Christian Post, November 11, 2005. http://www.christianpost.com <accessed December 13, 2012>.

41. Scaramanga, "Marketing Narnia: is that a Mouse in your Pulpit?," Christianity Today, December 6, 2005. http://www.outofur.com <accessed December 13, 2012>.

42. Michael Kress, "Sparking the Big Question," http://www.beliefnet.com/Entertainment/ Movies/Narnia/Sparking-The-Big-Questions.aspx, 2005 <accessed September 7, 2012>.

43. San Francisco Film Reviews and News, http://www.sf360.org/features/2006/05/ the_2006_san_fr.html <accessed December 15, 2007>.

44. In 2005, the American admissions reached 1.4 billion, down from 1.54 in 2004, and the average production costs of a studio film was $\$ 60$ million while its marketing cost stood at $\$ 36.2$ 
million. Motion Picture Association of America, U.S. Theatrical Market: 2005 Statistics, http:// www.mpaa.org <accessed June 22, 2006>.

45. Jeff Giles, “This just in : Movies don't make Money," Variety, November 13, 2007. http:// www.variety.com <accessed January 27, 2008>.

46. The next Narnia film might not be released before 2018. http://www.narniaweb.com $<$ accessed December 12, 2012>.

47. William D. Romanowski, Reforming Hollywood: how American Protestants Fought for Freedom at the Movies, 9.

48. For example James Russell, "Narnia as a Site of National Struggle," Cinema Journal, 484 (summer 2009): 59-76.

49. For example Holes (Andrew Davis, 2003), Because of Winn-Dixie (Wayne Wang, 2005), The Water Horse (Jay Russell, 2007), Journey to the Center of the Earth (Eric Brevig, 2008), The Tooth-Fairy (Michael Lembeck, 2010) or the soon-to-be-released reboot of Benji (Brandon Camp, 2013).

\section{ABSTRACTS}

The relationship between Hollywood studios and the American conservative Christians has always been a tricky one, as they are not an easy audience to satisfy. The surprising box office success of The Passion of The Christ (Mel Gibson, 2004) nevertheless underlined that, in some cases, the American conservative Christians, and more particularly the Protestant ones, can become a financial asset as a niche audience for Hollywood. This article describes the reasons that pushed the producers and distributors of The Chronicles of Narnia to take advantage of that niche audience. It shows how they did it and came to collaborate with the American Evangelicals, who make an extensive use of modern methods of communication and welcome such high-profile opportunities to spread God's word. But this article also demonstrates that in a globalized movie industry ruled by market shares and profits, Hollywood's overtures to the American conservative Christians cannot but be limited, as the latter remain a niche audience.

\section{INDEX}

Keywords: niche marketing, Hollywood studios, Evangelicals, Chronicles of Narnia, Walden Media

\section{AUTHOR}

\section{NATHALIE DUPONT}

Nathalie Dupont is an Associate Professor in American studies at ULCO (Université du Littoral \& de la Côte d'Opale). She has published several articles on the American film industry. Her research interests also include how Hollywood films reflect American society. She is a co-founder of research group CinEcoSA (http://www.cinecosa.com). She is currently writing a book on Walden Media. 